\title{
ALEKSANDER STĘPKOWSKI*
}

Uniwersytet Warszawski

\section{KSZTAŁTOWANIE SIĘ MIESZANEGO SYSTEMU SZKOCKIEGO PRAWA PRYWATNEGO W XIX I XX WIEKU}

\section{WPROWADZENIE}

W literaturze prawa porównawczego podkreśla się, że funkcjonujące niekiedy przeświadczenie o jednolitości Wysp Brytyjskich pod względem prawnym jest jak najbardziej błędne', zaś określenie „prawo brytyjskie” jest bardzo niejednoznaczne ${ }^{2}$. Szczególnie spektakularnym przykładem odrębności prawnych jest w tym przypadku prawo szkockie, w którego kształtowaniu się - z przyczyn politycznych - bardzo doniosłą rolę odegrały wpływy kontynentalnej kultury prawnej, przynoszącej ze sobą na tę część Wysp Brytyjskich spuściznę jurysprudencji rzymskiej. Nie oznacza to oczywiście, że prawo szkockie nie podlegało wpływom prawa angielskiego. Szczególnie sprzyjające warunki po temu powstały na początku XVIII wieku, kiedy to Szkocja i Anglia połączone zostały unią realną, tworząc Królestwo Wielkiej Brytanii. Zmienne

- Autor jest stypendystą Fundacji na rzecz Nauki Polskiej.

' Por. K. ZweIgerT - H. KöTZ, An Introduction to Comparative Law', tłum. T. Weir, Oxford 1998, s. 201.

${ }^{2}$ Por. M.A. Glendon - M.W. GoRdon - C. OsAWKe, Comparative Legal Traditions in a Nutshell, St. Paul-Minnesota 1982, s. 159-160. 
okoliczności polityczne stworzyły w ten sposób warunki do powstania w Szkocji specyficznego systemu prawa prywatnego, zawierającego w sobie zarówno elementy jurysprudencji rzymskiej jak i anglosaskiego prawa precedensowego.

$\mathrm{Na}$ świecie mamy do czynienia $\mathrm{z}$ wieloma równie specyficznymi systemami prawnymi, których kształt i funkcjonowanie stanowi bardzo złożoną problematykę, budzącą żywe zainteresowanie w literaturze prawa porównawczego ${ }^{3}$. Ich cechą charakterystyczną jest przede wszystkim to, że z punktu widzenia położenia geograficznego stanowią grupę nadzwyczaj rozproszoną. Wystarczy wskazać, że mieszane (mixed lub semi-civilian) - systemy prawa prywatnego mają m.in. takie kraje, jak Szkocja, Republika Południowej Afryki, Quebek, Louisiana i Cejlon. Jeśli jednak pominąć nawet ów czynnik znacznego rozproszenia geograficznego, utrudniającego - choć nie uniemożliwiającego ${ }^{4}$ - ich integrację, należy podkreślić, że sama ich specyfika niesłychanie utrudnia jakiekolwiek uprawnione uogólnienia.

${ }^{3}$ Por. E. ÖRÜCÜ - E. ATtwooll - S. CoYle, Studies in Legal Systems: Mixed and Mixing, London 1996; H. DAvid, Introduction à l'étude du droit écossais, Paris 1972; K. ZwEIGERT - H. KöTZ, An Introduction to Comparative Law, cit. s. 201-204, 231-235; TENŻE, The Civil Law Tradition in Scotland, red. EvANS - R. JONES, Edinburgh 1995; W.Q. FUNIAK de, The Legal System of Scotland, "Tulane Law Review» 38 (1963-1964), s. 91-102; A.D. GIBB, The Inter-relations of the Legal Systems of Scotland and England, "Law Quarterly Review» 53 (1937), s. 61-79; R. ZIMMERMANN - D. VISSER, South African law as a Mixed Legal System, [w:] Southern Cross. Civil Law and Common Law in South Africa, Oxford 1996, s. 1-30; W.M. GoRDON, Scotland as a Mixed Jurisdiction, [w:] Au-delà des frontièrs. Mélanges de droit romain offerts à Witold Wolodkiewicz, red. M. ZABLOCKA - J. KRZYNÓWEK - J. URBANIK - Z. SŁuŻEwSKA, I, Varsovie 2000, s. 323-331.; T.B. SMITH, Scots Law and RomanDutch Law. A Shared Tradition, «Juridical Review» 73 (1961), s. 32-52; TENŻE, English Influences on the Law of Scotland General and Historical, «American Journal of Comparative Law» 3 (1954), s. 522-542. A. WATSON, Legal Transplants. An Approach to Comparative Law ${ }^{2}$, Athens-London 1993, s. 36-56; J.A. LOVAT-FrASER, Some Points of Difference between English and Scotch Law, "Law Quarterly Review» 10 (1894), s. 340-347.

${ }^{4}$ Warto podkreślić, że szkoccy prawnicy utrzymują dość ożywione kontakty ze swymi południowoafrykańskimi kolegami 
Mówiąc o systemach mieszanych, należy poczynić pewne zastrzeżenia. Jak słusznie zauważa W. Gordon, z określenia takiego a contrario może wynikać, że istnieją jakieś „czyste” (wolne od obcych wpływów) systemy prawnes, a tego typu teza jest wysoce wątpliwa. Pojęcia mieszanych systemów prawnych można używać we właściwy sposób jedynie w odniesieniu do systemów zawierających elementy wywodzące się z różnych kultur prawnych, a nie do oddziaływań mających miejsce w obrębie jednej tylko ich rodziny. Należy też podkreślić, że recepcja pojedynczych rozwiązań z systemów anglosaskich do systemów romańskich lub na odwrót, również nie będzie prowadziła wprost do powstania sytemu, który można byłoby zakwalifikować jako mieszany. Owo wzajemne przenikanie się różnych kultur prawnych musi sięgać znacznie głębiej. Systemy mieszane nie mają bowiem charakteru eklektycznej konstrukcji składającej się - na podobieństwo sfinksa - z różnych, lepiej lub gorzej skomponowanych, elementów, lecz stanowią pewną nową jakość.

Pośród systemów tych można wyróżnić dwie grupy. Pierwszą $\mathrm{z}$ nich stanowi Szkocja i odrębne systemy prawne panujące na normandzkich wyspach Kanału La Manche - Jersey i Guernsey, gdzie historycznie mieszały się wpływy kontynentalnego ius commune i prawa angielskiego. W krajach należących do drugiej grupy, tworzenie się mieszanego systemu prawnego wynikało $\mathrm{z}$ konkurowania ze sobą morskich imperiów w procesie kolonizacji. Prawo angielskie mieszało się tutaj z hiszpańskim, holenderskim lub francuskim ${ }^{6}$. W grupie mieszanych systemów prawa prywatnego system szkocki odgrywa o tyle szczególną rolę, że od 300 lat tworzy część zunifikowanego organizmu państwowego z Anglią, będącą wszak kolebką anglosaskiego common law.

Właśnie unia realna z Anglią - choć nie od razu - stała się dominantą dla kierunku, w jakim przebiegał w XIX i XX stuleciu rozwój prawa szkockiego, które do tej pory można było zaliczyć do konty-

\footnotetext{
${ }^{5}$ Por. W.M. GoRdon, Scotland as a Mixed Jurisdiction, cit., s. 324.

${ }^{6}$ Por. T.B. SMITH, Studies Critical and Comparative, Edinburgh 1962, s. XV.
} 
nentalnej tradycji średniowiecznego ius commune ${ }^{7}$. Unia ta stanowiła w dużej mierze logiczną konsekwencję łączącej obydwa państwa od początku XVII wieku unii personalnej w osobach monarchów $\mathrm{z}$ dynastii Stuartów, którzy świadomie dążyli do pełnego zjednoczenia. Proces ten zaowocował w 1707 roku przyjęciem przez parlament szkocki, a następnie angielski (1708) ustaw łączących oba państwa w jeden unitarny organizm polityczny.

Wpływ prawa angielskiego na szkocki porządek normatywny nie następował jednak natychmiast po roku 1708. Całe osiemnaste stulecie jest tzw. okresem klasycznym w rozwoju prawa szkockiego, podczas którego nie tylko uniknęło ono wpływów angielskich, ale dodatkowo, jurysprudencja szkocka w tym czasie osiągnęła bardzo wysoki poziom rozwoju. Zachowanie odrębnego charakteru prawa szkockiego było możliwe dzięki postanowieniom, które zawierał traktat unijny w art. 18-21, a które gwarantowały odrębność dla systemu prawa materialnego i systemu sądownictwa obowiązującego w Szkocji w chwili wejścia unii w życie, dopuszczając uniformizację prawa jedynie w sytuacjach, gdy odbyłoby się to dla ewidentnego pożytku Szkotów ${ }^{8}$. Jednak zmiany społeczno-polityczne, jakie pociągnęła za sobą Unia z Anglią, nie mogły na dłużej pozostać bez konsekwencji dla kształtu prawa szkockiego i, mimo że wpływy prawa angielskiego w XVIII wieku i na początku wieku XIX były nie-

7 Tematyka wcześniejszego rozwoju prawa szkockiego została przedstawiona w odrębnej publikacji oddanej do druku w czasopiśmie «Studia Iuridica».

${ }^{8}$ Art. XVIII. THAT the Laws concerning Regulation of Trade Customs and such Excises to which Scotland is by virtue of this Treaty to be lyable be the same in Scotland from and after the Union as in England and that all other Lawes in use within the Kingdom of Scotland do after the Union and notwithstanding thereof remain in the same force as before (except such as are contrary to or inconsistent' with this Treaty) but alterable by the Parliament of Great Britain With this difference betwixt the Laws conceming Publick Right Policy and Civil Government and those which concern private Right That the Laws which concern publick Right policy and Civil Government may be made the same throughout the whole United Kingdom but that no alteration be made in Laws which concern private Right except for evident utility of the, subjects within Scotland. 
znaczne, już w połowie tego stulecia osiągnęły one bardzo poważne rozmiary. Oddziaływanie to miało trojaki charakter. $Z$ jednej strony należy wskazać na prawotwórczą i de facto często unifikującą działalność parlamentu brytyjskiego, $\mathrm{z}$ drugiej zaś strony na aktywność orzeczniczą sądu Izby Lordów oraz mniej zinstytucjonalizowany wpływ szeroko pojętej jurysprudencji angielskiej, odbywający się m.in. za pośrednictwem literatury prawniczej, ale nade wszystko angielskiego orzecznictwa precedensowego.

\section{POLITYCZNE KONSEKWENCJE UNII I ROZWÓJ PRAWA STANOWIONEGO}

Po wejściu w życie unii realnej w 1708 roku i zlikwidowaniu szkockiej Privy Council, która do tej pory sprawowała w Szkocji funkcję rządu, administracja terytorium północnej Brytanii formalnie znajdowała się w zakresie zadań brytyjskiej Privy Council, a następnie Sekretariatu Stanu (Home Secretary), praktycznie jednak funkcje te wykonywał Lord Advocate, który obok Solicitor General for Scotland, jest szkockim Law Officer Korony'.

W roku 1885 kompetencje administracyjne, które Home Secretary sprawował względem Szkocji, przejął nowoutworzony Sekretariat dla Szkocji (Secretary for Scotland), który w 1926 roku został podniesiony do rangi ministerstwa (Secretary of State for Scotland). Od tego

\footnotetext{
${ }^{9}$ Obydwie te funkcje mają charakter quasi-ministerialny i jako polityczne, obsadzane były przez premiera rządu brytyjskiego na czas sprawowania władzy przez daną ekipę rządzącą. Najczęściej funkcje te pełnili, dysponujący odpowiednimi kwalifikacjami, członkowie parlamentu. Obydwaj ci wysocy urzędnicy reprezentują interes Korony w postępowaniach cywilnych, jak również w istotniejszych sprawach karnych. Lord Advocate jest szefem prokuratury szkockiej (head of the system of public prosecution in Scotland) i przysługuje mu wyłączna kompetencja w sferze ścigania przestępstw, do osądzenia których właściwy jest szkocki wymiar sprawiedliwości. Urząd Lorda Adwokata (Lord Advocate's Department) zajmuje się jednak również sferą legislacji związaną ze Szkocją, wspólpracując ze Scottish Law Commission oraz opiniując projekty ustaw brytyjskich dotyczących Szkocji. Por. D.M. WALKer, The Scottish Legal System. An Introduction to the Study of Scots Law? , Edinburgh 1997, s. 357-358.
} 
momentu rozpoczęło się stopniowe przenoszenie urzędów $\mathrm{z}$ Londynu do Edynburga. W 1945 roku rozszerzono kompetencje tego ministerstwa i tendencja ta była kontynuowana w latach pięćdziesiątych, łącząc się $\mathrm{z}$ tworzeniem wielu szkockich urzędów ${ }^{10}$. Proces ten trwał do czasów współczesnych, znajdując swój finał w uzyskaniu w 1998 roku przez Szkocję autonomii w ramach Zjednoczonego Królestwa.

\section{Szkocja na forum parlamentu brytyjskiego}

Zasadnicza zmiana, którą przyniosła ze sobą unia realna, polegała na tym, że wyłączną kompetencję ustawodawczą, zarówno dla Anglii jak i dla Szkocji, od 1708 roku posiadał parlament Wielkiej Brytanii (od roku 1801 parlament Zjednoczonego Królestwa), który zastąpił dotychczas funkcjonujące zgromadzenia w Londynie i Edynburgu. W praktyce oznaczało to oczywiście przemożny wpływ Anglików na kształt legislacji, w Izbie Gmin było bowiem ich zawsze $\mathrm{z}$ górą dziesięciokrotnie więcej niż Szkotów. Ustawodawstwo brytyjskie było zatem $w$ istocie ustawodawstwem angielskim. Sytuacja ta sprawiła, iż ustawy dawnego parlamentu z Edynburga zaczęły być pieczołowicie hołubione przez Szkotów, którzy interpretowali je w bardzo dynamiczny sposób tak, aby mogły „służyć jak najdłużej”. Interpretując te dawne ustawy brano zatem pod uwagę wszelkie okoliczności pomagające dookreślić cel, jaki przed sobą stawiał ówczesny ustawodawca. Oczywiście sprawa przedstawiała się zupełnie odmiennie w przypadku ustaw brytyjskich, względem których stosowano tę samą wykładnię, jaką posługiwali się sędziowie angielscy, a zatem interpretowano ustawę w sposób „bardzo dosłowny”, odwołując się właściwie wyłącznie do formalno-dogmatycznej analizy tekstu" ${ }^{11}$.

XIX wiek w Wielkiej Brytanii to okres bardzo intensywnego rozwoju prawa stanowionego, wiążący się $\mathrm{z}$ reformistycznym ruchem

\footnotetext{
${ }^{10}$ Por. D.M. WALKER, The Scottish Legal System, cit., s. 152-154.

"Por. H. DAVID, Introduction à l'etude, cit., s. 83.
} 
reformy prawa (Law Reform Movement). Okoliczność ta, w połączeniu z brakiem zrozumienia ze strony Anglików dla odrębności prawa obowiązującego w północnej Brytanii, była jednym $z$ najistotniejszych czynników, wpływających na rozwój prawa szkockie$\mathrm{go}^{12}$. W parlamencie brytyjskim, ustawodawstwo traktowano niejednokrotnie jako narzędzie unifikacji prawnej całego kraju. Szczególne ożywienie tej integrującej działalności dało się zaobserwować począwszy od 1820 roku $^{13}$. Wiąże się to $z$ wieloma reformami, które zostały podjęte w Anglii przez liberalne rządy wigów w pierwszej ćwierci XIX wieku, inspirowanych w dużej mierze pracami Jeremy'ego Benthama i jego kontynuatorów. W Szkocji działania te postrzegano jako próby „zangielszczenia” tamtejszego prawa. Przedmiotem szczególnie gorących w tym czasie angielsko-szkockich polemik stało się m.in. prawo rodzinne, $w$ istotny sposób różniące się w obu porządkach prawnych, a którego ogólnobrytyjskiej unifikacji chcieli dokonać Anglicy.

Bardziej realny wpływ na tok legislacyjny w parlamencie londyńskim uzyskali Szkoci dopiero pod koniec XIX wieku. W 1894 roku powołano Scottish Grand Committee, który skupiał wszystkich szkockich parlamentarzystów. Dyskutowano tam nad projektami ustaw i opiniowano regulacje, które dotyczyły również prawa szkockiego. Było to jednak ciało bardzo silnie upolitycznione i nie zawsze kompetentne. Pewne usprawnienie nastąpiło po powołaniu w 1907 roku, funkcjonującego w sposób ciągły, Scottish Standing Committee, jednak przygotowanie merytoryczne jego członków wciąż nasuwało wątpliwości. W roku 1954 powołany został wreszcie Law Reform Committee for Scotland, przygotowujący raporty o stanie prawnym, które mogłyby być punktem wyjścia dla nowej legislacji. Jego działalność szybko straciła jednak znaczenie w związku z uchwaleniem w 1965 roku Law Commissions Act. Od tego czasu

\footnotetext{
${ }^{12}$ Por. K. ZwEIGERT - H. KötZ, An Introduction to Comparative Law, cit., s. 203.

${ }^{13}$ Por. T.M. CoOPER (Lord Cooper of Culross), Selected Papers 1922-1954, Edinburgh 1957, s. 180.
} 
działalność legislacyjna parlamentu westminsterskiego w znacznie większym stopniu uwzględniała szkocką specyfikę ${ }^{14}$, co nie znaczy, że problemy do tej pory istniejące zniknęły. Wynikało to $\mathrm{z}$ faktu, że funkcjonowało ogólne domniemanie, że prawo stanowione przez parlament londyński jest prawem brytyjskim - więc obowiązującym również w Szkocji, chyba że przepisy szczególne expressis verbis stanowią inaczej ${ }^{15}$. W praktyce te szczególne regulacje dotyczące Szkocji były umieszczane w artykułach końcowych (application section) ustaw bądź też były uchwalane w formie oddzielnych aktów prawnych dla Szkocji, co było uwidaczniane w tytule danej ustawy przez dodanie w nawiasie słowa Scotland przed wyrazem „Act”.

\section{Scottish Law Commission}

Ożywiona w XIX wieku działalność prawotwórcza parlamentu brytyjskiego, nie będąca czymś „normalnym” w kraju prawa precedensowego, stanowiła sukces Law Reform Movement. Ów ruch na rzecz reformy prawa, jak już wspomniano, tkwił swymi korzeniami w poglądach Jeremiego Benthama i filozofii utylitarystycznej, będąc silnie związanym $\mathrm{z}$ angielskim środowiskiem pozytywistów prawnych. Doczekał się on w drugiej polowie XX wieku swoistej instytucjonalizacji w postaci Komisji Prawa (Law Commission) ${ }^{16}$, utworzonej na mocy Law Commission Act 1965. Ustawa ta w sekcji 2 powołała również - obok komisji angielskiej - odrębną komisję prawną dla Szkocji. Miały one za zadanie rewizję istniejącego prawa $\mathrm{z}$ uwzględnieniem specyfiki obu systemów.

Scottish Law Commission ma zatem formułować propozycje konsolidacji i rewizji dotychczasowych regulacji ustawowych w celu uwspółcześnienia prawa, sugerować reformy regulacji dysfunkcyj-

${ }^{14}$ Działalności Scottish Law Commission poświęcony jest artykuł, Lorda HUNTER, Law Reform: The Scottish Law Commission, «Juridical Review» 102 (1988), s. 158.

${ }^{15}$ Por. T.B. Smith, Studies Critical and Comparative, cit., s. 122.

${ }^{16}$ Por. J.H. BAKER, An Introduction to English Legal History ${ }^{3}$, London 1993, s. 248-249. 
nych, uwzględniając przy tym wiedzę na temat rozwoju prawa w innych krajach ${ }^{17}$. Miało się to odbywać między innymi przez częściową kodyfikację, likwidację anomalii, usunięcie niepotrzebnych aktów prawnych i scalanie poszczególnych cząstkowych regulacji w większe ustawy tak, aby uczynić prawo prostszym i bardziej spójnym $^{18}$. Scottish Law Commission składa się z przewodniczącego

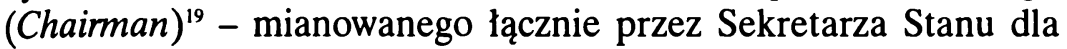
Szkocji (od 1999 roku Pierwszego Ministra Scottish Executive) i Lorda Adwokata - oraz trzech członków ${ }^{20}$. W czasie swego funkcjonowania Komisja ogłosiła sześć programów reformy prawa (kolejno w roku 1965, 1968, 1973, 1990, 1997 i w marcu roku 2000). Efektem tych działań są między innymi uchwalane co pewien czas Law Reform (Scotland) Acts. Poza realizacją kolejnych programów reformy prawa szkockiego, na mocy sekcji 3(1)(e) Law Commissions Act 1965, na wniosek Ministrów podejmowane są przez to gremium dodatkowe prace, mające na celu rozwiązywanie bieżących problemów prawnych, $\mathrm{z}$ jakimi borykają się aktualne rządy.

Wraz z powstaniem szkockiej Komisji i określeniem zakresu jej zadań na porządku dziennym stanęla również problematyka kodyfikacji prawa szkockiego. Jak podkreśla się w literaturze, pod wpły-

\footnotetext{
${ }^{17}$ Por. D.M. WALkER, Reform Restatement and the Law Commissions, «Juridical Review» 68 (1956), s. 251.

${ }^{18}$ The Law Commissions Act 1965 w sekcji 3(1) stwierdza, że do zadań obydwu komisji należy: ... to take and keep under review all the law with which they are respectively concerned with a view to its systematic development and reform, including in particular the codification of such law, the elimination of anomalies, the repeal of obsolete and unnecessary enactments, the reduction of the number of separate enactments and generally the simplification and modernisation of the law... Por. szerzej na ten temat H. DAVID, Introduction à l'etude, cit., s. 68-69. Por. także D.M. WALKER, The Scottish Legal System, cit., s. 579.

${ }^{19}$ Kolejnymi przewodniczącymi Scottish Law Commission byli sędziowie Court of Session Lord Kilbrandon (1965), Lord Hunter (1971), Lord Maxwell (1981), Lord Davidson (1988), zaś od 1996 roku jest nim Lord Gill.

${ }^{20}$ Pierwszymi czlonkami komisji byli: Prof. Halliday (Glasgow), Prof. Smith (Edynburg) oraz G.D. Fairbairn. Por. D.M. WALKER, Reform Restatement, cit., s. 255.
} 
wem angielskim odrzucona została przez Szkotów idea kodyfikacji na dużą skalę ${ }^{21}$. Zaznaczyć jednak należy, że w ograniczonym zakresie była ona wielokrotnie wcielana w życie w sposób analogiczny do tego, w jaki uczyniono to w Anglii, choć idea zebrania szkockiego prawa prywatnego w usystematyzowanych aktach prawnych - ze względu na skład parlamentu brytyjskiego - nie zawsze cieszyła się tak wielkim uznaniem w Szkocji, jak można by było wnioskować z niektórych wypowiedzi. Sceptycyzm w tym względzie szczególnie silnie dał znać o sobie w XIX wieku, jednak dwudzieste stulecie przyniosło pod tym względem dużą zmianę. Przeważać zaczęły wówczas opinie, że kodyfikacja jest najlepszym wyjściem dla szkockiego prawa prywatnego - co więcej, całkowicie realnym do przeprowadzenia. Należy jednak zaznaczyć, że można było również spotkać wypowiedzi, w których kodyfikacja była postrzegana jako proces niekorzystny, i z tego względu bliskie związki z prawem angielskim traktowane były jako dobroczynne, bo chroniące przed ujęciem prawa w formę kodeksu'22.

W tym kontekście uchwalenie Law Commission Act 1965 stanowiło duże wsparcie dla zwolenników kodyfikacji prawa szkockiego, którzy coraz częściej wyrażali przekonanie, że właśnie kodyfikacja jest najlepszym i jedynym racjonalnym sposobem systematyzacji prawa $^{23}$. Jednak należy od razu podkreślić, że przez ponad 30 lat niewiele uczyniono w tym kierunku i dopiero współcześnie problematyka ta może doczekać się ponownego podjęcia.

Powstanie Scottish Law Commission, stanowiło zatem dla Szkotów instytucjonalną gwarancję poszanowania odrębności ich systemu prawnego na gruncie ustawodawczym. Jednak należy podkreślić, że angielskie wpływy odbywały się również na innych płaszczyznach, pośród których newralgiczną pozycję zajmowało sądownictwo.

${ }^{21}$ Por. T.M. CoOPER (Lord Cooper of Culross), Selected Papers, cit., s. 182.

2 Por. M.G. Fisher, Scotland and the Roman Law, «Tulane Law Review» 22 (1947), s. 20.

${ }^{23}$ Por. D.M. WALKER, Reform Restatement, cit., s. 261; por. także T.B. SMITH, The Doctrine of Judicial Precedent in Scots Law, Edinburgh 1952, s. 103. 


\section{PRZEMIANY W SZKOCKIM WYMIARZE SPRAWIEDLIWOŚCI}

\section{Reforma sądownictwa centralnego}

W pierwszej połowie XVI wieku, królom szkockim, po wielu nieudanych próbach udało się stworzyć działający permanentnie centralny sąd szkocki - Court of Session, będący najwyższym trybunalem w kraju. Obowiązywała w nim - powszechna wówczas w Europie - procedura rzymsko-kanoniczna. Sąd ten od momentu powstania do początku XIX wieku działał w zasadzie w niezmieniony sposób $^{24}$, co z czasem odbiło się na sprawności jego funkcjonowania. Przez blisko 300 lat Court of Session działał zatem jako jednolity sąd obradujący w pełnym składzie sędziowskim, $\mathrm{z}$ nielicznymi tylko wyjątkami, kiedy to delegowano dwu lub trzyosobowe składy do zajmowania się czynnościami wstępnymi. Tworzyły one wówczas tzw. Outer House, w odróżnieniu od Inner House, czyli właściwego trybunału orzekającego.

Traktat unijny zawierał w art. 19 gwarancję dla sądów szkockich co do ich przyszlego istnienia i nie uszczuplonych kompetencji25. Court of Session rozszerzył nawet w niewielkim stopniu swą właściwość w związku z likwidacją szkockiej Privy Council, która poza funkcjami administracyjnymi wykonywała m.in. nadzwyczajną słusznościową kompetencję Korony, pozwalającą na zapobieganie niesprawiedliwym rozstrzygnięciom, które mogą wynikać z niedoskonałości prawa. Court of Session przejął częściowo tę kompetencję w wymiarze, w jakim ustawodawstwo szkockie otwarcie przyznawało taką jurysdykcję Privy Council. Jednak de facto była ona sprawowana również w wielu innych przypadkach, niezależnie od

\footnotetext{
${ }^{24}$ Por. D.M. WALKER, The Scottish Legal System, cit., s. 138.

${ }^{25}$ XIX. THAT the Court of Session or Colledge of Justice do after the Union and notwithstanding thereof remain in all time coming within Scotland as it is now constituted by the Laws of that Kingdom and with the same Authority and Priviledges as before the Union subject nevertheless to such Regulations for the better Administration of Justice as shall be made by the Parliament of Great Britain...
} 
istnienia podstawy ustawowej. Ta część nie została inkorporowana przez Court of Session do zakresu jego właściwości i w efekcie została bezpowrotnie utracona ${ }^{26}$.

Owo niewielkie rozszerzenie kompetencji Court of Session nie stanowiło w istocie zmiany w jego funkcjonowaniu, które w XVIII wieku spotykało się z licznymi krytykami. Zostały one podchwycone na początku XIX wieku przez reformatorskie rządy wigów, które rozpoczęły prace nad zmianami w funkcjonowaniu Court of Session, co dopuszczał art. 19 traktatu unijnego. Planowana reforma, na której kształt wywierał wpływ również Jeremy Bentham, opierała się na wzorach angielskich ${ }^{27}$ i była nieco rozciągnięta w czasie. W 1808 roku Inner House został podzielony na dwa wydziały (division). Na czele jednego stał Lord President przewodząc siedmiu lordom zwyczajnym (Lords ordinary), na czele drugiej Lord Justice-Clerk przewodząc sześciu lordom zwyczajnym. Lordowie zwyczajni obu wydziałów (divisions) zasiadali też okresowo w Outer House. Jednak od 1810 roku siedmiu najmłodszych lordów zwyczajnych (odpowiednio czterech i trzech w każdej division) zostało na stałe delegowanych jako sędziowie w Outer House, który stał się w ten sposób sądem pierwszej instancji. Obecnie w Outer House zasiada 18 młodszych (Junior) Lords of Session $^{28}$ orzekających pojedynczo, niekiedy tylko $\mathrm{z}$ dwunastu lawnikami $^{29}$. W Outer House są rozpatrywane w pierwszej instancji

\footnotetext{
${ }^{26}$ Por. P.G.B. McNeILl, The Passing of the Scottish Privy Council, «Juridical Review» 68 (1956), s. 263-264.

${ }^{27}$ Por. A.J. MACLEAN, Jeremy Bentham and the Scottish Legal System, «Juridical Review» 93 (1979), s. 21-24.

${ }^{23}$ Skład osobowy Outer House stanowią: Lady Cosgrove oraz lordowie: Milligan, Cameron of Lochbroom, Marnoch, MacLean, Penrose, Osborne, Abernethy, Johnston, Gill, Hamilton, Dawson, Macfadyen, Nimmo Smith, Philip, Kingarth, Bonomy, Eassie, Reed.

${ }^{29} \mathrm{~W}$ Szkocji udział przysięgłych w procesie jest przejawem wpływów angielskich i poddawany jest krytyce, jednak wciąż wiele spraw, które wymienia sekcja dziewiąta Court of Session Act 1988 jest rozstrzyganych przy ich udziale.
} 
wszystkie sprawy, które nie zostały przez ustawę włączone w zakres właściwości innego sądu.

W Inner House, składającym się z ośmiu sędziów, orzekają dwie równorzędne czteroosobowe divisions. Orzekają one zazwyczaj w pełnym składzie, choć trzech sędziów stanowi quorum, które można osiągnąć również przez zapraszanie sędziów z drugiej division lub z Outer House. W sprawach szczególnie ważkich i nastręczających dużych trudności prawnych orzekają niekiedy łącznie obie divisions jako Court of Seven Judges. Mogą one nawet uzupełniać dodatkowo swój skład o kolejnych sędziów tworząc skład trzynastoosobowy. Inner House zasadniczo jest trybunałem apelacyjnym od wyroków wydanych w sądzie szeryfa lub wyroków zapadłych w Outer House. Zupełnie wyjątkowo jednak zdarza się, iż Inner House wypowiada się w pierwszej instancji w sprawach nastręczających szczególnych problemów prawnych. Dotyczy to przede wszystkim interpretacji testamentów i wykonywania tzw. nobile officium ${ }^{30}$.

\section{Zmiany w procedurze}

Jak już wspomniano w sądach szkockich funkcjonowała zasadniczo od XIII wieku procedura oparta na wzorcach rzymsko-kanonicznych, chociaż istniały też pewne podobieństwa do reguł proceduralnych obowiązujących we Francji. Postępowanie przed Court of Session było bowiem regulowane przez jego wewnętrzne akty (Acts of Sederunt), które miały być bardzo zblizone do analogicznych regulacji wewnętrznych obowiązujących w parlamentach francuskich ${ }^{31}$.

Procedura w tym kształcie sprawiała, że postępowania przed sądem były długotrwałe. W połowie XIX wieku pojawiły się w Szkocji głosy nawołujące do zmiany prawa w kierunku jego większego upodobnienia do prawa angielskiego. Tendencje te były szczególnie silne w kręgach szkockiego biznesu z Glasgow, gdzie powstało

\footnotetext{
${ }^{30}$ Por. D.M. WALKER, The Scottish Legal System, cit., s. 278 - 279.

${ }^{31}$ Por. T.B. SMITH, Studies Critical and Comparative, cit., s. 40, 42.
} 
Glasgow Law Amendment Society. Środowiska te domagały się m.in. ograniczenia, na wzór angielski, zasady pisemności obowiązującej w sądzie, jak również ograniczenia prawa do apelowania ${ }^{32}$. Uproszczenia procedury były dokonywane częściowo przy uchwalaniu różnych ustaw. W efekcie jednak, na mocy Court of Session Act 1868 udało się ulepszyć i usprawnić procedurę przez wprowadzenie w szerokim zakresie procedury ustnej, co w zasadniczy sposób uprościło postępowanie przed tym trybunałem, chociaż powodowato zarzuty o nadmierną inspirację procedurą angielską. Usprawniono także postępowanie dowodowe. W 1913 roku został uchwalony Consolidating Act of Sederunt ujednolicający dotychczasowe - bardzo rozproszone - regulacje proceduralne. W 1936 roku natomiast, na podstawie Administration of Justice (Scotland) Act 1933, Court of Session opracował swoje Rules of Court ${ }^{33}$. Obecnie sąd ten działa na podstawie Court of Session Act 1988 oraz opracowanych na jego podstawie w 1994 roku Rules of the Court of Session.

\section{Sądy szeryfów}

Najniżej w strukturze sądownictwa szkockiego usytuowane są sądy szeryfów. Powołane zostały one na wzorcach normandzkich przez Dawida I (1124-1153). Szybko szeryfami zaczęto mianować znacznych feudałów, którzy z czasem zaczęli ten urząd piastować dziedzicznie. Sądy szeryfów, choć miały szeroki zakres właściwości (sprawy cywilne i karne, zarówno prawo osobowe jak i ziemskie), funkcjonowały bardzo źle. Począwszy od XV wieku podejmowano liczne próby ich zreformowania, jednak $\mathrm{z}$ ograniczonymi sukcesa$\mathrm{mi}^{34}$. Z czasem godność szeryfa utraciła charakter dziedzicznej godności feudalnej, a pod koniec XVIII wieku osoba orzekająca w tym sądzie zaczęła być opłacana przez państwo, stając się regularnym

${ }^{32}$ Por. I.G.C. Hutchison, A Political History of Scotland 1832-1924. Parties Elections and Issues, Edinburgh 1986, s. 93-94.

${ }^{33}$ Por. D.M. WALKER, The Scottish Legal System, cit., s. 138-140.

${ }^{34}$ Por. H. DAvID, Introduction à l'etude, cit., s. 109-111. 
urzędnikiem. Ten trwający wiele lat proces profesjonalizacji sądów szeryfa zakończył się jednak dopiero w roku 1825, gdy wprowadzono wymóg, iż szeryf musi być wykwalifikowanym prawnikiem ${ }^{35}$.

Obecnie Szkocja podzielona jest na sześć szeryfostw (Sherifdoms). Na czele każdego z nich stoi Sheriff Principal, sprawujący nadzór nad sprawnym funkcjonowaniem sądów szeryfów działających na terytorium jego Sherifdom. Każde $\mathrm{z}$ owych szeryfostw jest podzielone na kilka okręgów, w których znajduje się jeden sąd szeryfa. W sumie w Szkocji funkcjonuje czterdzieści dziewięć takich sądów. Rozstrzygają one sprawy o zapłatę długu lub odszkodowania (bez ograniczenia wysokości przedmiotu sporu), są właściwe w zakresie prawa rodzinnego oraz w sprawach $\mathrm{z}$ zakresu kontraktów, deliktów, jak również prawa spadkowego, gdy przedmiot sporu nie przekracza 1500 funtów. Niektóre sprawy mogą być przekazywane z sądów szeryfa do Court of Session. Dotyczy to w szczególności procesów dotyczących Korony lub związanych ściśle $\mathrm{z}$ innymi postępowaniami toczącymi się przed Court of Session. Przekazanie takie dodatkowo może nastąpić w sytuacji, gdy z innych przyczyn Court of Session wydaje się stosowniejszy, lub gdy takiego przekazania zażąda. Szeryf orzeka jednoosobowo i tylko w niektórych przypadkach wyrokowanie odbywa się przy udziale siedmioosobowej lawy przysięgłych. Apelacje od jego wyroku są rozstrzygane bądź przez Principal Sheriff (od wyroków którego przysługuje odwołanie do Inner House Court of Session), bądź bezpośrednio przez Inner House. W sprawach o niewielkiej wysokości przedmiotu sporu apelacja przysługuje jedynie do Sheriff Principal ${ }^{36}$.

\section{Sąd Izby Lordów najwyższą instancją odwoławczą}

Jak już wspomniano, traktat unijny w artykule 19 zawierał m.in. gwarancje dla systemu sądownictwa szkockiego. Przewidywały

\footnotetext{
${ }^{3 s}$ Por. W.Q. DE FUnIAK, op.cit., s. 96-97; D.M. WALKER, The Scottish Legal System, cit., s. 125-126.

${ }^{36}$ Por. D.M. WALKER, The Scottish Legal System, cit., s. 273-276.
} 
one, że w przyszłości żaden z sądów westminsterskich nie będzie właściwy w sprawach z zakresu prawa szkockiego ${ }^{37}$. Wkrótce jednak okazało się, że mimo usilnych zabiegów nie udało się wyłączyć wszystkich angielskich sądów od rozstrzygania spraw szkockich. Od orzeczeń Court of Session przysługiwał przed unią nadzwyczajny środek w postaci odwołania do parlamentu jako sądu najwyższej instancji. Po unii bardzo szybko pojawiły się apelacje od wyroków Court of Session do sądu Izby Lordów, o którym nie było mowy w traktacie unijnym. Pierwszą taką próbę podjęto już na przełomie roku 1707 i 1708, kiedy to House of Lords w sprawie Earla of Rosebery uznała swą właściwość, choć sama apelacja nie została uwzględniona. Jednak na pierwszy skuteczny precedens nie trzeba było długo czekać i w roku 1710 w sprawie Jamesa Greenshielda Izba uwzględniła apelację uchylając wyrok Court of Session. Od tej pory szkockie apelacje zaczęły napływać regularnie do Izby Lordów ${ }^{38}$ i rozpoczął się dość kontrowersyjny rozdział w jej orzecznictwie, któremu nierzadko zarzucano arogancję $\mathrm{i}$ ignorancję ${ }^{39}$. Szczególnie często lordowie angielscy (Lords of Appeals) uchylali decyzje Court of Session w pierwszej połowie XIX wieku, stosując w sprawach szkockich prawo angielskie, co było wyraźnie widoczne w sposobie argumentowania, w ramach którego nie trudzono się nawet, by tłumaczyć terminologię angielską na szkocką. Lordowie angielscy nie przyjmowali po prostu do wiadomości faktu, że prawo szkockie różni się od angielskiego, również wówczas, gdy wartość przedmiotu sporu (w XIX wieku) wynosiła setki tysięcy funtów.

Jak zauważył profesor A. Dewar Gibb, angielscy sędziowie Izby Lordów orzekali w przeświadczeniu o słuszności i sprawiedliwości

\footnotetext{
${ }^{37}$ Por. tamże, s. 120.

${ }^{38}$ Por. A.D. GIBB, op.cit., s. 64; por. także D.M. WALKER, The Scottish Legal System, cit., s. 123.

${ }^{39}$ Niektórzy autorzy szkoccy zresztą nie przebierają w epitetach określając tę działalność chociażby jako „strata czasu”. Por. D.M. WALKER, The Scottish Legal System, cit., s. 136, 282.
} 
rozwiązania danego zagadnienia prawnego w myśl określonej zasady angielskiej i byli przekonani, iż zasada ta powinna obowiązywać w systemach prawnych wszystkich cywilizowanych narodów. Jeśli więc prawo szkockie chce być postrzegane jako prawo narodu cywilizowanego, to musi to rozwiązanie przyjąí $\dot{c}^{40}$.

Ten stan rzeczy wywoływał w Szkocji wiele protestów. W latach sześćdziesiątych XIX wieku zaczęto czynić starania o zapewnienie obecności szkockiego sędziego w składzie orzekającym Izby Lordów. Jednocześnie starano się też na drodze ustawowej zlikwidować kontrowersyjną kompetencję Izby Lordów. Udało się to formalnie w 1873 roku na mocy The Judicature Act, ale odnośne postanowienie nie weszło nigdy w życie i szybko zostało derogowane. W ustawie Appellate Jurisdiction Act 1876, udało się jedynie na trwałe zapewnić obecność Szkota w składzie Izby Lordów ${ }^{41}$.

Jednak również to rozwiązanie wywoływało w Szkocji sceptyczne komentarze. Lord Cockburn przykładowo, jeszcze w 1852 roku stwierdził, że Szkot poza swą ojczyzną szybko ulegnie wpływom angielskiego common law. Wskazywał on również, że nie ma żadnych gwarancji, że funkcję tę sprawować będą osoby najodpowiedniejsze ${ }^{42}$. Podkreślić trzeba również, że sędziowie szkoccy nigdy nie są w większości w składzie orzekającym Izby Lordów, choć niektórzy z nich, jak lordowie Watson czy Reid, cieszyli się najwyższym uznaniem również orzekając w sprawach z zakresu prawa angielskiego ${ }^{43}$. Tutaj jednak należy dodać, że

\footnotetext{
${ }^{40}$ Por. T.B. SMITH, Studies Critical and Comparative, cit., s. 123.

"Sędziami tymi byli kolejno lordowie: Watson, Robertson, Shaw of Dufermline, Duendin, Macmillan, Thankerton, Normand, Reid, Keith of Avonholm, Guest, Kilbrandon, Fraser of Tullybelton, Keith of Kinkel, Mackay of Clashfern, Jaunce of Tulliechettle, Hope of Craighead and Clyde. Okazjonalnie zasiadali też w Sądzie Izby Lordów inni szkoccy sędziowie, którzy akurat byli ówcześnie Parami, między innymi byli to Lordowie Kinnear i Shand. Por. D.M. WALKER, The Scottish Legal System, cit., s. 138.

${ }^{42}$ Por. T.B. SMITH, Studies Critical and Comparative, cit., s. 124.

${ }^{43}$ Por. D.M. WALKER, The Scottish Legal System, cit., s. 136-138, 145.
} 
przynajmniej w przypadku lorda Watsona obawy Cockburna się potwierdziły, a profesor Gibb określił go nawet jako doughty angliciser, bowiem lord Watson odpowiedzialny był za przeszczepienie wielu zasad angielskich na grunt prawa szkockiego, w czym sekundowali mu też inni lordowie szkockiego pochodzenia, jak chociażby lord Robertson ${ }^{44}$.

Podkreślić jednak należy, że sami Szkoci stwierdzają wielokrotnie również wzbogacający szkocką doktrynę wpływ orzecznictwa Izby Lordów $w^{45}$. Co więcej, znane są przypadki, kiedy to Izba Lordów musiała uchylić decyzję Court of Session, który zbyt daleko inspirował się prawem angielskim i pomijał wywodzące się $\mathrm{z}$ prawa rzymskiego zasady, stosowania których należało się po nim spodziewać. Przykładem może być tutaj głośna sprawa Cantiere San Rocco S.A. v. The Clyde Shipbuilding \& Engineering Co. Ltd. $(1923)^{46}$, kiedy Court of Session oparł swój wyrok na angielskim precedensie ze sprawy Candler v. Webster, $(1904)^{47}$, nie uznając powództwa na podstawie condictio causa data causa non secuta, co zostało skorygowane dopiero przez Izbę Lordów ${ }^{48}$.

Sytuacja może ulec zmianie w związku $\mathrm{z}$ wejściem w życie postanowień Scotland Act 1998 i postępujących procesów uzyskiwania przez Szkocję coraz większej autonomii w ramach Zjednoczonego Królestwa. 8 kwietnia 1999 roku Szkocka Partia Narodowa opublikowała manifest $\mathrm{w}$ związku z pierwszymi wyborami do autonomicznego parlamentu szkockiego, w którym zapowiadano zniesienie możliwości apelacji do Izby Lordów od orzeczeń Court of Session. Jak do tej pory jednak, deklaracja ta nie pociągnęła za sobą konkretnych posunięć.

${ }^{44}$ Por. T.B. SMITH, Studies Critical and Comparative, cit., s. 124.

${ }^{45}$ Por. tamże, s. 125.

${ }^{46}$ Cantiere San Rocco S.A. v. The Clyde Shipbuilding \& Engineering Co. Ltd., 1923 S.C. (H.L.) 105; 1923 S.L.T. 624.

${ }^{47}$ Candler v. Webster, [1904] 1 K.B. 493.

${ }^{48}$ Por. P. STEIN, The Influence of Roman Law on the Law of Scotland, "Juridical Review» 75 (1963), s. 244. 


\section{PRAWO PRECEDENSOWE}

Pisząc o prawie szkockim, jako o systemie mieszanej jurysdykcji nie sposób pominąć zagadnienia sposobu, w jaki dokonuje się owo mieszanie różnych kultur. W przypadku Szkocji mamy bowiem do czynienia nie tylko ze wzajemnym przenikaniem się różnych rozwiązań materialno-prawnych. Jedną $\mathrm{z}$ zasadniczych różnic między obydwoma europejskimi kręgami kulturowymi jest nade wszystko sposób, w jaki są one rozwijane ${ }^{49}$. Mówiąc zatem o mieszaniu się kontynentalnej kultury prawnej $\mathrm{z}$ tradycją prawa anglosaskiego nie sposób nie poruszyć zagadnienia doniosłości prawnej precedensu sędziowskiego.

\section{Historyczna doniosłość precedensu w Szkocji}

Prawo szkockie miało - a porównując je do prawa angielskiego można powiedzieć, że jest tak w dalszym ciągu - charakter dedukcyjny, zatem był mu obcy anglosaski sposób rozumowania from case to case. Cechę tę podkreślał Lord Advocate Macmillan wskazując, że decyzje sądów szkockich są podejmowane w oparciu o zasady, a nie precedensy ${ }^{50}$. Niektóre dziedziny prawa były rozwijane jako judge-

\footnotetext{
${ }^{49}$ Nie sposób rozważać w tym miejscu kwestii sposobu, w jaki rozwijane było prawo rzymskie w starożytności i dużych analogii $z$ anglosaskim systemem precedensowym. Mowa jest tutaj raczej o sposobie rozwijania prawa w tradycji cywilistycznej niż o samym prawie rzymskim, które nie będąc wprawdzie porządkiem sensu stricto precedensowym, jednak było rozwijane, szczególnie w jego okresie klasycznym, w sposób będący w wielu momentach bardzo zbieżny w swej metodzie ze sposobem w jaki kształtowane były doktryny angielskiego prawa precedensowego. Por. P. STEIN, Regulae Iuris. From Juristic Rules to Legal Maxims, Edinburgh 1966, s. 102-103; L. VACCA, La giurisprudenza nel sistema delle fonti del diritto romano. Corso di lezioni, Torino 1989, s. 108-109; oraz recenzja tej książki P. STEIN, «Studia et Documenta Historiae et Iuris» 65 (1989), s. 490. Bardzo trafne uwagi na ten temat można odnaleźć również w artykule T. GiaRo, L'art de comparer les cas, «Studia et Documenta Historiae et Iuris» 60 (1994), s. 527.

so Por. A. Rodger, Thinking about Scots Law, «Edinburgh Law Review» 1 (1996), s. 9.
} 
made law, jednak stosunek do precedensu był tu zasadniczo odmienny niż w Anglii. Autorzy Instytucji twierdzili, że dopiero seria podobnych decyzji może doprowadzić do ustalenia prawa, chociaż sędziowie Court of Session, co do zasady, wzajemnie respektują swe decyzje i wyrokując, jedynie wyjątkowo i po starannym namyśle, decydują się na rozstrzygnięcie inne od tego, które wynika $z$ wcześniejszych decyzji. Podejście to nie miało zatem nic wspólnego z zasadą stare decisis, w myśl której wiążący charakter mają nawet pojedyncze orzeczenia. Zatem, mimo że wypowiedzi sędziów z XVIII wieku wskazują na duży szacunek dla wcześniejszego orzecznictwa, jednak podkreśla się w nich, że sędzia nie jest obligowany w myśl angielskiej zasady. Co więcej, zdarzały się wypowiedzi wskazujące na niecelowość wnikliwego studiowania ciągle rozrastającego się orzecznictwa ${ }^{51}$.

Również w XIX wieku spotkać można podobne opinie, jak chociażby wyrażoną przez profesora $\mathrm{D}$. Chape w jego wykładzie wygłoszonym 13 listopada 1827 roku, w którym stwierdził, że w nowoczesnym systemie prawnym prawdopodobnie nikt nie chciałby opierać swych uprawnień na autorytecie precedensu ${ }^{52}$. Mimo to jednak, z początkiem XIX wieku rozpoczyna się proces zapuszczania w Szkocji korzeni przez doktrynę stare decisis. Przyczyn tego zjawiska jest kilka, najważniejszym jednak czynnikiem była działalność House of Lords, bowiem zapadłe tam decyzje musiały być traktowane tak jak traktuje się je w Anglii, czyli z pełnym rygoryzmem zasady stare decisis. Z drugiej strony, autorytet pojedynczych decyzji Court of Session również wzrósł, gdy sąd ten został podzielony na początku XIX wieku na dwa wydziały (divisions), przez co sędziowie zyskali więcej czasu, aby gruntowniej uzasadnić wyroki, a tym samym skłonni byli przywiązywać do nich większą wagę. Wciąż jednak w Szkocji można było na przestrzeni całego XIX wieku spotkać opinie zarówno sędziów, jak i prawników akademickich, z których jasno wynikało, że mają obiekcje co do tego, by pojedynczą decyzję

${ }^{\text {s1 }}$ Por. T.B. SмIтH, The Doctrine of Judicial Precedent, cit., s. 4-6.

52 Por. A. Rodger, op.cit., s. 10. 
sądu traktować jako natychmiastowo i automatycznie wiążącą, $\mathrm{z}$ wyjątkiem decyzji House of Lords i pełnego - siedmioosobowego składu Court of Session (Court of Seven Judges). Dodać należy, że również w XX wieku można było spotkać opinie, że błędny wyrok nie jest wiążący dla później rozstrzyganych spraw ${ }^{53}$

\section{Doktryna wiążącego precedensu w Szkocji}

Opisywana uprzednio reforma Court of Session, stała się niezwykle istotnym czynnikiem determinującym metodę pracy szkockich prawników. Dzięki zmianom w funkcjonowaniu tego sądu - jak była już o tym mowa - wzrosła znacznie rola orzecznictwa precedensowego w Szkocji, co się objawiło m.in. rozpoczęciem regularnego publikowania oficjalnych zbiorów orzeczeń Court of Session. Okoliczności te zadecydowały o tym, że prawo szkockie zaczęło się rozwijać jako porządek stricte precedensowy. Dodatkowo sprzyjała temu procesowi popularność teorii Savigny'ego o prawie będącym wytworem ducha narodu, przy założeniu, że orzecznictwo sądów można traktować jako manifestację tego ducha ${ }^{54}$.

Generalnie Szkoci podkreślają, że bardziej ich interesuje zasada niż pojedynczy wyrok. Dlatego też przywiązują oni znacznie mniejsze znaczenie do stanów faktycznych poszczególnych spraw. W odniesieniu do orzecznictwa Court of Session zasada stare decisis nie została nigdy wyraźnie sformułowana, więc - chociaż oczywisty jest respekt dla niej-jednak w wyjątkowych sytuacjach (np. gdy ratio decidendi jest niejasna) sąd może zdecydować się na to, by zignorować jakąś decyzję wydając nowy wyrok. Court of Session wypracował również praktykę, iż zasady sformułowane w sposób budzący kontrowersje mogą być poddawane rewizji przez cały Inner House. Po-

\footnotetext{
${ }^{53}$ Por. T. B. SmITH, The Doctrine of Judicial Precedent, cit., s. 10-14.

${ }^{54}$ Por. P. STEIN, The Influence of Roman Law on the Law Scotland, cit., s. 243; Por. także J.W. CRAINS, The Influence of German Historical School in Early Nineteenth Century Edinburgh, «Syracuse Journal of International Law and Commerce» 20 (1994), s. 202-203.
} 
dobnie pewne zasady prawa mogą zostać zmienione $\mathrm{z}$ uwagi na zmianę warunków społecznych. Precedens może więc zostać zignorowany, jeśli przyczyna, dla której zapadło dane rozstrzygnięcie, nie pozostaje dłużej aktualna w związku ze zmianą okoliczności (cessante ratione legis cessat lex ipsa). Obecnie w Szkocji z pełnym rygoryzmem zasady stare decisis przestrzegane są decyzje House of Lords wydane przy rozstrzyganiu szkockich apelacji. Orzeczenia wydane przez Izbę Lordów w innych sprawach, choć są starannie brane pod uwagę, jednak nie są traktowane jako wiążące. Jeśli jednak w jakiejś sprawie „nie szkockiej” House of Lords zajął stanowisko inne niźli wcześniej w apelacji od wyroku Court of Session, to sąd ten czuje się zwolniony od przestrzegania dotychczasowego orzecznictwa.

Jeśli chodzi o niższe instancje, lordowie orzekający w Outer House są związani decyzjami zapadłymi w Inner House. Ich decyzje $\mathrm{z}$ kolei nie są wiążące dla szeryfów, obowiązanych jedynie do przestrzegania decyzji zapadłych w Inner House, bowiem zarówno Outer House of Court of Session, jak i Sheriff Courts są sądami pierwszej instancji. Orzecznictwo Sheriff Principal, co do zasady, jest respektowane przez trybunały szeryfów w danym Sherifdom ${ }^{\text {ss }}$.

\section{Precedens jako nośnik wpływów angielskich}

Prawnicy szkoccy, obok orzecznictwa Izby Lordów, zaczęli się w XIX wieku bardzo chętnie powoływać się również na angielskie precedensy pochodzące $\mathrm{z}$ sądu działającego $\mathrm{w}$ Westminster Hall. Profesor Smith podkreślał, że „cytowanie angielskich precedensów stało się pod koniec XIX wieku coraz bardziej powszechne i bezkrytyczne. Ta praktyka spowodowała zamieszanie w szkockich zasadach prawnych, do tej pory właściwie stosowanych. Gotowe rozwiązania stały się we wszystkich dziedzinach bardzo atrakcyjne dla zabieganych praktyków"s6. Wytłumaczenie tego zjawiska daje obecny

\footnotetext{
${ }^{s 5}$ Por. T. B. SmITH, The Doctrine of Judicial Precedent, cit., s. 103-108.

${ }^{\text {s6 }}$ Por. T.B. Smith, Studies Critical and Comparative, cit., s. 112.
} 
Lord President Court of Session Alan Rodger, który wskazuje, że „o ile doktryny prawne są oczywiście bardzo interesującym przedmiotem rozważań pośród prawników, to ich klienci nie są nimi w najmniejszym nawet stopniu zainteresowani. Wszystko czego klient wymaga, to tego, by wygrać w sądzie. Będzie on żądał użycia wszelkiego argumentu, nagięcia każdej doktryny i wyszukania jakiegokolwiek precedensu, po to tylko, by zapewnić sobie sukces"s7. Cytowanie angielskich orzeczeń było niegdyś bardzo niepopularne w Court of Session ${ }^{\text {s8 }}$, jednak, jak twierdził lord Watson, odkąd funkcję Lord Justice-Clerk zaczął sprawować John Inglis, cytowanie angielskich decyzji zaczęło być mile widziane, a od roku 1878 (od sprawy City of Glasgow Bank ${ }^{59}$ ), praktyka ta stała się zjawiskiem codziennym $^{60}$. Z badań przeprowadzonych już XX wieku wynika, że około jedna czwarta precedensów powoływanych przed Court of Session w tym stuleciu to orzeczenia sądów angielskich ${ }^{61}$.

Zjawisko to jest złożone. Angielskie precedensy w dużej mierze ilustrują sposób stosowania zasad dawno już w prawie szkockim uznanych za wiążące (recognised) i obowiązujące. Jeszcze więcej jednak spośród tych orzeczeń wiąże się ze stosowaniem zunifikowanego prawa brytyjskiego (dotyczy to chociażby prawa handlowego i prawa spółek). Ponadto należy zaznaczyć, że nie wszystkie precedensy powoływane przez strony procesu i odnotowywane w statystykach są uwzględniane, mając w ten sposób wpływ na kształtowanie prawa ${ }^{62}$. Jako przykład może tutaj posłużyć sprawa ${ }^{63}$, w której Lord Justice-Clerk Dickinson nie uwzględnił angielskich precedensów jako nie odpowiadających prawu szkockiemu. Zresztą można

${ }^{57}$ Por. A. Rodger, op.cit., s. 9.

${ }^{88}$ Por. T.B. SMITH, Studies Critical and Comparative, cit., s. 126.

${ }^{59}$ Gillespie v. City of Glasgow Bank, (1879) 6R. 714; 6R (H.L.) 104.

${ }^{60}$ Por. A. Rodger, op.cit., s. 16.

"Por. C. McDiarmid, Scots Law: The Turning of the Tide, «Juridical Review» 113 (1999), s. 161-162; oraz tekst do którego odsyła następny przypis.

${ }^{62}$ Por. T.B. SmITH, Studies Critical and Comparative, cit., s. 125.

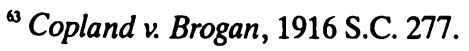


się spotkać w literaturze $\mathrm{z}$ uwagami wskazującymi, że powoływane orzecznictwo angielskie często nie jest właściwe w sprawie, w której się je wysuwa ${ }^{64}$. Dodatkowego kolorytu dostarcza tutaj fakt, że przed sądami szkockimi przywołuje się nierzadko precedensy angielskie, które już nie są traktowane jako wiążące przez sąd, który je wydał ${ }^{65}$. Sama zatem statystyczna wzmianka co do proporcji powoływanych precedensów szkockich i angielskich nie daje jeszcze informacji o rzeczywistym rozmiarze angielskich wpływów na prawo szkockie ${ }^{66}$.

Jest jednak więcej przyczyn, dla których Szkoci tak często sięgają po orzecznictwo angielskie. Należy bowiem uwzględnić fakt, iż ze względu na okoliczności obiektywne Court of Session wydaje znacznie mniej wyroków niż sądy angielskie, które dostarczają w ten sposób dalece obfitszego materiału służącego do argumentacji przed sądem $^{67}$. Podkreśla się jednak, że angielskie wyroki winny być brane pod uwagę dopiero w przypadku luki w szkockich zasadach precedensowych, wskazując na zagrożenia wynikające z posługiwania się angielskim orzecznictwem przez osoby nie w pełni zorientowane w odrębnościach obydwu tych systemów prawnych ${ }^{68}$.

\section{ROLA JURYSPRUDENCJI SZKOCKIEJ}

Zarysowany powyżej proces upodabniania prawa szkockiego do angielskiego common law nie pozostawał bez reakcji ze strony Szkotów. Za najlepszy sposób obrony przed niepożądanymi wpływami prawa angielskiego uznawali oni studia nad prawem rzym-

${ }^{4}$ Por. C. McDiarmid, Scots Law: The Turning of the Tide, cit., s. 162.

${ }^{\text {as }}$ Por. G. Gretton, Scotland: The Evolution of the Trust in a Semi-Civilian System, [w:] Itinera Fiduciae. Trust and Treuhand in Historical Perspective, red. R. HelmholZ - R. ZimmermanN, Berlin 1998, s. 530.

${ }^{6}$ Por. T. B. SMITH, Studies Critical and Comparative, cit., s. 125.

${ }^{67}$ Por. C. McDiarmid, Scots Law: The Turning of the Tide, cit., s. 163; por. T.B. Smith, Studies Critical and Comparative, cit., s. 135.

${ }^{68}$ Por. T. B. SmITH, Studies Critical and Comparative, cit., s. 126-127. 
skim. W tej sytuacji argumentów na obronę odrębności szkockiego porządku prawnego dostarczyła niemiecka szkoła historyczna w prawoznawstwie ${ }^{69}$. Wiązało się to między innymi z niechętnym stosunkiem Szkotów do angielskich projektów kodyfikacyjnych.

Osobą, która położyła bodaj największe zasługi w krzewieniu wiedzy na temat niemieckiej szkoły historycznej w prawoznawstwie oraz prawa rzymskiego w Szkocji był David Irving - kustosz Advocates' Library w Edynburgu (1820-1848), autor książki Observations on the Study of the Civil Law, który utrzymywal ożywione kontakty m.in. z belgijskimi zwolennikami szkoły historycznej skupionymi wokół periodyku Themis ou Bibliothèque du Jurisconsulte. Jako kustosz Biblioteki Adwokatów miał on zasadniczy wpływ na dobór nabywanych przez nią książek, wśród których dominowały niemieckie prace przedstawicieli szkoły historycznej ${ }^{70}$. Popularność tych poglądów w Szkocji pozwalała przeciwstawiać się do pewnego stopnia wpływom angielskim.

Dzięki temu prawo szkockie mogło obronić swą odrębność w XIX wieku. W efekcie niektórzy spośród autorów twierdzą, że współcześnie jest ono w dużym stopniu tworem XIX-wiecznym, wynikającym z rozwoju dyscyplin historyczno-prawnych, ze szczególnym uwzględnieniem zmieniającej się roli, jaką w szkockim systemie odgrywało prawo rzymskie ${ }^{71}$. Być może przypisywanie szkole historycznej tak dużej roli jest twierdzeniem przesadnym, jednak wydaje się, że nie sposób bagatelizować tego wpływu, który stanowil przeciwwagę dla daleko idącej infiltracji ze strony prawa angielskiego.

Właśnie w XIX wieku pojawia się termin institutional writings, używany na określenie prac, które traktowane są jako deklaracja obowiązującego w Szkocji prawa. Szczególny status, jakim zaczęły się wówczas cieszyć te XVII i XVIII-wieczne prace, wynikał rów-

\footnotetext{
${ }^{69}$ Por. J.W. CRAINS, The Influence of German Historical School, cit., s. 200-201.

${ }^{\top}$ Por. tamże, s. 196.

${ }^{71}$ Por. tamże, s. 191.
} 
nież z wpływów niemieckiej szkoły historycznej ${ }^{72}$. Prace te odegrały ogromną rolę w rozwoju prawa szkockiego, stanowiąc swoisty symbol jego odrębności jako systemu narodowego. Najwięcej pozycji, które dostąpiły zaszczytnego statusu Instytucji, powstało w okresie szkockiego oświecenia, a więc pod koniec wieku XVII i w wieku XVIII. Stanowią one w ten sposób prawniczy wkład do dorobku intelektualnego tej epoki, którą zazwyczaj kojarzy się z twórczością filozoficzną i ekonomiczną oraz postaciami Davida Hume'a i Adama Smitha.

Jednym z pierwszych autorów Instytucji był Lord Stair. Publikacja w roku 1681 jego Institutes of the Laws of Scotland, deducted from its originals and collated with the Civil, Canon and Feudal Laws and with the Customs of Neighbouring Nations, uważana jest przez Szkotów za symboliczny moment powstania ich prawa jako narodowego, odrębnego i spójnego systemu ${ }^{73}$. Wiek XVIII przynosi kolejne pozycje zaliczane do kanonu instytucji. Są to przede wszystkim prace Andrew McDoualla, lorda Bankton An Institute of the Laws of Scotland (1751-1753) oraz Johna Erskine of Carnock, profesora prawa szkockiego w Edynburgu, Institute of the Law of Scotland, wydane pośmiertnie w roku 1773 . XIX wiek przynosi prawu szkockiemu kolejne prace o najwyższym autorytecie i znaczeniu. Nade wszystko chodzi tutaj o wydane w 1810 roku Commentaries on the Law of Scotland and on Principles of Mercantile Jurisprudence George'a Josepha Bella. Zasługą Bella jest w istocie stworzenie szkockiego prawa handlowego oraz zharmonizowanie go $\mathrm{z}$ orzecznictwem angielskim ${ }^{74}$. Innym ważnym autorem był sędzia Court of Session lord John McLaren, autor monumentalnego dzieła Law of Wills and Succession as Administered in Scotland.

Obecnie, te napisane kilkaset lat temu książki, wciąż cieszą się wielkim autorytetem. Przytoczyć można w tym miejscu wypowiedź

\footnotetext{
7 Por. tamże, s. 203.

${ }^{73}$ Por. T.M. COOPER (Lord Cooper of Culross), Selected Papers, cit., s. 41.

${ }^{74}$ Por. tamże, s. 41; Por. także D.M. WALKER, The Scottish Legal System, cit., s. 144.
} 
lorda Benholme w sprawie Drew v. Drew $(1870)^{75}$, który stwierdzil, że gdy odnajduje w jakiejkolwiek sprawie niekwestionowaną opinię Staira, traktuje ją jako wyrażającą prawo szkockie. Można się spotkać ze stwierdzeniami, że opinie Staira są równie wiążąc dla Court of Session jak wyroki Izby Lordów w szkockich apelacjach. W obrębie prawa prywatnego wymienia się pośród prac o walorze Instytucji dzieła Craiga, Staira, McDouaalla, Erskine'a i Bella, chociaż niekiedy dodaje się do nich też trzech innych autorów (Mackenzie, Home, Kames) ${ }^{76}$.

Ten szczególny gatunek literatury prawniczej - kompendium prawa służące zarówno praktykom jak i studentom - pozostaje wciąż nadzwyczaj istotny w Szkocji. Spektakularnymi, choć nie jedynymi, przykładami tego gatunku w XX wieku, są kompendia autorstwa Gloaga i Hendersona The Law of Scotland, wyd. 1, 1927 (obecnie najnowsze, wyd. 10 pod red. W.A. Wilson - A. Forte, Edinburgh 1995) oraz pięciotomowe Principles of Scottish Private Law Davida Walkera, (najnowsze -4 wydanie, Oxford 1988-1989) ${ }^{n}$.

\section{SZKOCJA JAKO TERYTORIUM AUTONOMICZNE}

Zabiegi Szkotów zmierzające do podkreślenia swej odrębności, z perspektywy brytyjskiej wiążą się ściśle z szerszą problematyką dewolucji (devolution), czyli dekoncentracji władzy państwowej. Zagadnienie to przejawia się jednak nie tylko w dążeniach poszczególnych grup narodowościowych, takich jak Szkoci i Walijczycy, do uzyskania wielu swobód politycznych z autonomią włącznie. Dotyczy ono bowiem również kwestii samorządu terytorialnego, choć dla obecnych rozważań istotny jest jedynie wymiar narodowy tej problematyki.

\footnotetext{
${ }^{75}$ Drew v. Drew (1870) 9 M. 163, na s. 167: ... when on any point of law I find Stair's opinion uncontradicted, I look upon that opinion as ascertaining the Law of Scotland.

${ }^{76}$ Por. D.M. WALKER, The Scottish Legal System, cit., s. 456-457.

${ }^{n} \mathrm{Na}$ temat tych pozycji jako współczesnych Instytucji por. A. WATSON, Legal Transplants, cit., s. 38-39.
} 
Dążenia dewolucyjne Szkotów przyjmowały w drugiej połowie $\mathrm{XX}$ wieku różną postać. W latach siedemdziesiątych hasło to było traktowane przez brytyjskich polityków jako antidotum na wyraźne w ówczesnym okresie dążenia separatystyczne, które dały o sobie znać na Wyspach Brytyjskich. W 1978 roku projekt ustawy dewolucyjnej nie stał się obowiązującym prawem tylko $\mathrm{z}$ powodu zbyt niskiej frekwencji Szkotów, którzy w referendum wyrazili wolę uzyskania znacznej autonomii w ramach Zjednoczonego Królestwa ${ }^{78}$. Współcześnie zagadnienie to wiąże się bardziej $\mathrm{z}$ tendencjami decentralizacyjnymi, które towarzyszą procesowi integracji w ramach struktur Unii Europejskiej.

Wśród polityków brytyjskich, jeśli chodzi o stosunek do tego zagadnienia, wyraźny jest podział, który pokrywa się $w$ istocie $\mathrm{z}$ tradycyjnym zróżnicowaniem angielskiej sceny politycznej. Konserwatyści zajmują wobec tego procesu stanowisko wyraźnie niechętne, z kolei Partia Pracy, szczególnie zaś jej odłam New Labour, uczyniła $\mathrm{z}$ szeroko rozumianej dewolucji jeden $\mathrm{z}$ podstawowych elementów swego programu odnowy demokratycznej (democratic renewal), pod której hasłami objęła rządy w Wielkiej Brytanii w latach dziewięćdziesiątych ${ }^{79}$. Sukces wyborczy pozwolił na realizację wielu elementów tego programu, w wyniku czego Szkocja uzyskała autonomię.

Wraz z ukonstytuowaniem się autonomicznego parlamentu szkockiego, na podstawie sekcji 1(1) Scotland Act $1998^{80}$, powstały

${ }^{78}$ Por. M.A. Glendon - M.W. Gordon - C. OsAWKe, Comparative Legal Traditions in a Nutshell, St. Paul-Minnesota 1982, s. 161.

${ }^{x}$ Por. A. ZIĘBA, Wspótczesne brytyjskie doktryny polityczne, Białystok 2001, s. 82, 140-143, 204.

${ }^{80}$ Pełen tytul tej ustawy brzmi: An Act to provide for the establishment of a Scottish Parliament and Administration and other changes in the government of Scotland; to provide for changes in the constitution and functions of certain public authorities; to provide for the variation of the basic rate of income tax in relation to income of Scottish taxpayers in accordance with a resolution of the Scottish Parliament; to amend the law about parliamentary constituencies in Scotland; and for connected purposes. 
zupełnie nowe perspektywy rozwoju dla prawa szkockiego. Ustawa ta-zgodnie z brzmieniem sekcji 37 - zmienia postanowienia ustaw parlamentu szkockiego i angielskiego o unii z 1707 roku. Jej podstawową przesłanką było powierzenie autonomicznemu, wybieranemu w wyborach powszechnych, parlamentowi szkockiemu, kompetencji ustawodawczej ${ }^{81}$. Jest ona jednak ograniczona do kwestii dotyczących wyłącznie Szkocji. Ów zakres kompetencyjny jest opisywany negatywnie, przez wyliczenie sfer, w których urzędujący w Edynburgu parlament tej kompetencji nie ma (sekcja 29) oraz pozytywnie przez zestawienia zawarte w schedule 4 i 5.

Oprócz autonomicznego organu ustawodawczego Szkocja otrzymała równiez, na mocy sekcji 44, własne władze wykonawcze Scottish Executive. Członkami Egzekutywy szkockiej są: Pierwszy Minister (First Minister), ministrowie, których on mianuje, oraz Law Officers for Scotland - czyli Lord Advocate i Solicitor General (sekcja 44). Na funkcję Pierwszego Ministra mianuje Królowa osobę desygnowaną przez parlament Szkocji spośród jego członków. Pierwszy Minister (za zgodą parlamentu) rekomenduje Królowej osoby mające pełnić funkcje Lorda Adwokata i Radcy Generalnego, oraz osoby wiceministrów (sekcje 48-49).

$\mathrm{Z}$ uzyskaniem autonomii niektóre spośród środowisk prawniczych wiążą nadzieje na oczyszczenie prawa szkockiego $\mathrm{z}$ angielskich naleciałości i na jego - niezależny od prawa angielskiego rozwój82. Warto przypomnieć, że już pół wieku temu prof. Smith wskazywał, że funkcjonowanie autonomicznego organu legislacyjnego jest jednym z podstawowych czynników pozwalających zachować cywilistyczny charakter tym systemom mieszanym (mixed, semi-civilian) prawa prywatnego, które są wystawione na silne oddziaływanie anglosaskiego common law ${ }^{83}$. W tym kontekście nie

\footnotetext{
${ }^{81}$ Scotland Act 1998, sekcja 28(1) Subject to section 29, the Parliament may make laws, to be known as Acts of the Scottish Parliament. Por. także C. MCDIARMID, Scots Law: The Turning of the Tide, cit., s. 167.

${ }^{82}$ Por. C. McDiaRmid, Scots Law: The Turning of the Tide, cit., s. 156, 164-165.

${ }^{\circledR}$ Por. T.B. SMITH, Studies Critical and Comparative, cit., s. 75.
} 
bez znaczenia pozostaje fakt, że w dalszym ciągu funkcjonuje Scottish Law Commission, której praca obecnie będzie mogła się w większym stopniu przekładać na konkretne działania legislacyjne. Członków Komisji mianuje obecnie Pierwszy Minister Szkockiej Egzekutywy ${ }^{84}$.

Zaznaczyć jednak należy, że na mocy sekcji $28(7)^{85}$ kompetencje legislacyjne parlamentu edynburskiego formalnie nie naruszają dotychczasowych uprawnień Izb obradujących w Westminster. Oczywiście przypadek skorzystania $\mathrm{z}$ nich $\mathrm{w}$ zakresie, $\mathrm{w}$ jakim kompetencje posiada parlament szkocki, spowodowałby wiele politycznego zamieszania i Szkoci nie ukrywają, że gotowi są na konfrontację w obronie uzyskanych koncesji ustawodawczych ${ }^{86}$.

\section{NOWE PERSPEKTYWY ROZWOJU PRAWA W SZKOCJI}

Autonomia uzyskana na mocy Scotland Act 1998 może stanowić punkt zwrotny w rozwoju prawa szkockiego jako spójnego systemu prawnego. Działalność parlamentu szkockiego ma według wielu autorów zahamować niepożądany wpływ norm angielskich i umożliwić zwrócenie baczniejszej uwagi na klasyczne, dawne prawo szkockie, do którego współczesny system powinien nawiązywać ${ }^{87}$. Trudno przewidzieć, czy rzeczywiście rozwijające się prawo szkockie będzie nawiązywać do tradycji, zważywszy, że nie brak również bardziej sceptycznych postaw. Obecny Lord President of Court of Session, Alan Rodger, podnosi oczywiste trudności, jakich współcześnie nie sposób uniknąć, nawiązując do klasycznych (osiemnastowiecznych) instytucji. Twierdzi on, że te -

${ }^{\text {s }}$ W lutym 2000 roku nastąpiły pewne zmiany w składzie komisji. Jej nowymi członkami na okres 2 lat zostali profesorowie Joe Thomson oraz Gerry Maher, którzy zastąpili dra Eryka Clive i Nialla Whitty.

ss 28 (7) This section (28/1/ - przyp. A.S.) does not affect the power of the Parliament of the United Kingdom to make laws for Scotland.

${ }^{86}$ Por. C. McDiarmid, Scots Law: The Turning of the Tide, cit., s. 167-168.

${ }^{87}$ Por. tamże, s. 156, 167. 
skądinąd wybitne - prace są w dużej mierze bezużyteczne we współczesnym obrocie prawnym ${ }^{88}$.

Zwolennicy renesansu jurysprudencji szkockiej wskazują jednak na fakt, że dzięki funkcjonowaniu nowego parlamentu będzie można podjąć bardziej skuteczną i przemyślaną reformę prawa, gdyż prace ustawodawcze nad nią nie będą już uzależnione od programu legislacyjnego dla całego Zjednoczonego Królestwa. Wiąże się to również ściśle z aktywnością Scottish Law Commission, która od tej pory nie będzie już całkowicie uzależniona od parlamentu brytyjskiego. Główny cel, jaki stawia sobie Komisja - systematyczny rozwój i reforma prawa szkockiego - będzie mógł być skutecznie realizowany przez ustawową implementację wyników jej prac. Zasadniczą rolę w tym procesie odegrają też środowiska akademickie. Doniosłość ich działalności była zresztą podkreślana już od dawna ${ }^{89}$. Obecnie, zarówno publikacje naukowe, jak i te o profilu bardziej zawodowym, stanowić będą zaplecze intelektualne dla działalności Scottish Law Commission i parlamentu ${ }^{90}$.

Do rangi symbolu można tutaj podnieść fakt, że Scottish Law Commission w ostatnim - szóstym, programie reformy prawa umieścila - choć w bardzo ograniczonym zakresie - problematykę kodyfikacji szkockiego prawa cywilnego i karnego. Była to reakcja na podjęte na Uniwersytecie w Edynburgu działania mające na celu przygotowanie projektu kodyfikacji szkockiego prawa karnego oraz cywilnego ${ }^{91}$. Ponadto programem tym objęto m.in. zagadnienia dotyczące systemu rejestracji praw rzeczowych, dotyczących nieruchomości, niektóre kwestie z zakresu prawa zobowiązań (irritancies) oraz norm regulujących sytuację prawną zarządców sądowych (judicial factors). Gruntownej reformie ma zostać poddane również prawo dotyczące kompetencji przysługujących właścicielom po-

\footnotetext{
${ }^{8}$ Por. A. RoDgER, op.cit., s. 14.

${ }^{\circ}$ Por. T.B. SMITH, Studies Critical and Comparative, cit., s. 86.

${ }^{90}$ Por. C. McDiarmid, Scots Law: The Turning of the Tide, cit., s. 164-167, 169.

${ }^{91}$ Por. (2000) Scot Law Com No 176, paragraf 1.33, s. 9; a także E.M. Cuive, Current Codification Projects in Scotland, «Edinburgh Law Review» 4 (2000), s. 341-350.
} 
wierniczym. Ponadto, prowadzone będą działania mające na celu konsolidację fragmentarycznych regulacji ustawowych dotyczących poszczególnych dziedzin prawa, między innymi publicznej służby zdrowia (National Health Service), policji, systemu sądownictwa szkockiego, jak również zdrowia psychicznego (mental health) ${ }^{92}$.

Warto przy tej okazji zwrócić uwagę na wypowiedź jednego spośród pierwszych członków Scottish Law Commission, profesora Halliday, która dość dobrze oddaje stosunek Szkotów do inspiracji kontynentalną kulturą prawną. Zauważył on, że Szkoci mogą szukać inspiracji do poprawiania swego prawa, tak jak miało to miejsce w przeszłości, również po drugiej stronie Morza Północnego. Jednak Komisja nie powinna równie chętnie zapożyczać rzymskich lub kontynentalnych konstrukcji, jak niektórzy ze szkockich sędziów i adwokatów naśladowali połowicznie rozumiane zasady angielskie $^{93}$. Warto jednak podkreślić, że w XX wieku zarówno bardzo poważni naukowcy, jak i sędziowie twierdzili, że rzymskie teksty zawarte w justyniańskim Corpus Iuris Civilis nadal są kopalnią praktycznych rozwiązań współczesnych problemów prawnych i powinny w dalszym ciągu wpływać na linię orzecznictwa szkockich sądów ${ }^{94}$. W istocie, współcześnie nadal spotyka się w orzecznictwie powoływane teksty prawa rzymskiego, jednak to nie one wydają się stanowić ratio decidendi. Prawo rzymskie nie stanowi również najczęściej obowiązkowego przedmiotu na studiach prawniczych. Wyjątkiem pod tym względem jest Uniwersytet w Aberdeen, choć wykładane jest ono tam w znacznie ograniczonym wymiarze ${ }^{95}$.

${ }^{2}$ Por. (2000) Scot Law Com No 176, s. 11-18.

${ }^{93}$ Por. D.M. WALKer, Reform Restatement, cit., s. 255-256.

${ }^{9}$ Por. T.B. SmITH, Studies Critical and Comparative, cit., s. 74, 117; por. także M.G. FisHER, Scotland and the Roman Law, «Tulane Law Review» 25 (1947), s. 21. Nie brak jednak w tej materii rozbieżności i opinii bardziej sceptycznych. Por. D.L. CAREY Miller, The Use of Roman Law in Scotland: a Reply, «Juridical Review» 87 (1975), s. 64-69.

${ }^{95}$ Por. W.M. Gordon, Roman Law in Scotland, [w:] The Civil Law Tradition in Scotland, red. R. Evans-JoNES, Edinburgh 1995, s. 59 
Wielu też wybitnych prawników szkockich jest dość sceptycznie ustosunkowanych do tendencji wiążących przyszłość prawa szkockiego $\mathrm{z}$ odrodzeniem go jako systemu nawiązującego do kontynentalnej kultury prawnej. Obecny Lord President Court of Session twierdzi, że bardzo szczęśliwą okolicznością dla porządków prawnych obowiązujących w ramach brytyjskiej Wspólnoty Narodów był fakt, iż sąd Izby Lordów orzekał zarówno w sprawach angielskich jak i szkockich, zaś apelacje z całego Imperium mogły być rozstrzygane przez trybunał, w którym, obok angielskich, zasiadali również sędziowie szkoccy" ${ }^{\%}$. Prezydent Court of Session zdecydowanie woli postrzegać prawo szkockie jako część szerszego porządku prawnego, obwiązującego w całej Commonwealth, wskazując na rosnącą w ostatniej dekadzie liczbę powoływanych przed sądami precedensów z zamorskich dominiów Wspólnoty" ${ }^{97}$. Również Scottish Law Commission w poszukiwaniu inspiracji prawno-porównawczej jest zdecydowanie bardziej skłonna do czerpania nie $\mathrm{z}$ romanistycznej tradycji, lecz z rozwiązań obecnych we współczesnych systemach prawa precedensowego $0^{98}$.

Powyższe uwagi należy odczytywać w kontekście obecnego w literaturze szkockiej podejścia do historycznego rozwoju tego systemu prawnego jako produktu komparatystyki prawniczej. Wskazywał na to chociażby lord Cooper podnosząc, że przez 500 lat rozwoju swego prawa Szkocja była „domem prawa porównawczego", zaś szkocki prawnik był eklektycznym filozofem. Chętnie, choć krytycznie, poznawal on obce systemy prawne, z którymi miał kontakt, i szybko włączał do swego prawa każde dobre rozwiązanie bez względu na jego rodowód ${ }^{99}$.

A. Rodger wydaje się nawiązywać do tego sposobu postrzegania prawa szkockiego, wskazując na zasadniczą jedność różnych syste-

\footnotetext{
${ }^{\text {\% }}$ Por. A. Rodger, op.cit., s. 22.

${ }^{97}$ Por. tamże, s. 17, 20.

* Por. W.M. Gordon, Roman Law, cit., s. 59.

${ }^{99}$ Por. T.M. CoOPER (Lord Cooper of Culross), Selected Papers, cit., s. 142.
} 
mów common law obowiązujących na całym świecie. Sugeruje on, że prawo szkockie powinno szukać swej tożsamości właśnie w ramach tej wspólnoty. Lord President przyznaje, iż - mimo dużego zbliżenia do prawa angielskiego - pozostaje ono wciąż przedziwną mieszaniną elementów rodzimych, rzymskich i angielskich. Jednak podkreśla, że przodkowie współczesnych Szkotów nie przejawiali niepokoju co do tego, którego z elementów tej mieszaniny używali jako najlepiej odpowiadającego wyzwaniom konkretnego czasu. Wskazuje, że współcześnie to pragmatyczne podejście powinno być kontynuowane, przez co prawo szkockie nie będzie może nigdy doskonale koherentnym systemem, ale za to będzie odpowiadało na wyzwania niesione przez zmieniającą się rzeczywistość. ${ }^{100}$

Trudno dziś przewidzieć, w jakim kierunku ewoluować będzie prawo szkockie w XXI wieku. Wydaje się jednak, że obecnie przeważają w północnej części Wielkiej Brytanii nastroje separatystyczne i wszelka odrębność - w tym również w zakresie prawa - będzie chętnie podkreślana i akcentowana. Należy też zaznaczyć, że prawo szkockie powinno odegrać szczególną rolę w procesie ujednolicania rozwiązań prawnych, właściwych dla jurysprudencji anglosaskiej, z konstrukcjami wywodzącymi się z prawa rzymskiego. Przekonanie to, w odniesieniu do integracji całych systemów prawnych, wyrażane było już od dawna w literaturze prawa porównawczego ${ }^{101}$, w której proces ten jest postrzegany jako nieunikniony.

\section{Formation OF THE MIXED SySTEM OF SCOTTISH PRIVATE LAW DURING $19^{\text {TH }}$ AND $20^{\text {TH }}$ CENTURIES}

(Summary)

This paper presents development of Scots law as a mixed jurisdiction in 19th and 20th centuries. This specific mixture of legal cultures

\footnotetext{
${ }^{100}$ Por. A. Rodger, op.cit., s. 23-24.

${ }^{101}$ Por. R. DAVID, Les grands systèmes de droit contemporains (droit compare), Paris 1964, s. 21; M.A. GLENDON-M.W. GoRDON - C. OSAWKE, Comparative Legal Traditions, cit., s. 160; K. ZWEIGERT - H. KöTZ, An Introduction to Comparative Law, cit., s. 204.
} 
which is Scots law, owes most of its peculiarity to, variable in its character, relationships with England and its precedent based legal culture. English influence on Scottish private law become predominant in 19th century, as an effect of advancement of internal integration within United Kingdome.

Scots law - as described in 18th century classical legal treaties - was in general based on continental ius commune, as presented in French and Roman-Dutch legal thought. Political and social consequences of the Union of 1707 allowed extremely intensive influence of English law in Scotland since second quarter of 19 th century. This impact had miscellaneous character and was performed in a various ways. The easiest one was legislative activity of British Parliament, whose statutes in 19th century started to be progressively more and more important source of English law. Statutory influence was the easiest as the number of Scots in British Parliament never exceeded ten percent, so there was no problem in ignoring their objections, until the establishment of the Scottish Law Commission in 1965, which started to supervise legislation touching Scotland.

Except statutory influence, considerable changes took place in the way of administering justice in Scotland. The most spectacular was decision of the House of Lords which in the beginning of 18th century had recognised its authority to revise judgements of the Court of Session - Scottish supreme court. In effect House of Lords started - regardless differences existing between Scots law and English law - to apply English rules in reviewing judgements of the Court of Session. Further influence of English rules into Scots law was provoked by the reform of the Court of Session, whose organisation and proceedings became considerably anglicised. It provoked that its decisions started to be regarded as a primary source of law by progressive acceptance of English stare decisis rule - which was not the part of Scottish legal system before.

A kind of reaction for this process of Anglicisation was the interest of Scottish lawyers in studies of Roman law, as performed on continent in Netherlands and Germany. This interest subsequently was manifested in following ideas of German historical school. In consequence they started to underline the unique - domestic - character of Scots law, independent as well from English law as from continental tradition of civil law. 
The article is finishing with considerations upon possible consequences for Scots law of the process of devolution in Scotland which took place in 1998. It presents different opinions of Scottish lawyers, as to the future development of Scots law. 